\title{
MAPPING OF QTLS RELATED WITH WOOD QUALITY AND DEVELOPMENTAL CHARACTERISTICS IN HYBRIDS (Eucalyptus grandis $X$ Eucalyptus urophylla) ${ }^{1}$
}

\author{
Rodrigo Barros Rocha ${ }^{2}$, Everaldo Gonçalves Barros², Cosme Damião $\mathrm{Cruz}^{2}$, Antônio Marcos Rosado e \\ Elza Fernandes de Araújo ${ }^{2}$
}

\begin{abstract}
The present work aimed to characterize and identify QTLs for wood quality and growth traits in E. grandis $\mathrm{x}$ E. urophylla hybrids. For this purpose a RAPD linkage map was developed for the hybrids $(\mathrm{LOD}=3$ and $\mathrm{r}=0.40$ ) containing 52 markers and 12 linkage groups. Traits related to wood quality and growth were evaluated in the QTL analyses. QTL analyses were performed using chi-square tests, single-marker, interval mapping and composite interval mapping analyses. All approaches led to the identification of similar QTLs associated with wood density, cellulose pulp yield and percentage of extractives, which were detected and confirmed by both the interval mapping and composite interval mapping methodologies. Some QTLs regions were confirmed only by the composite interval mapping methodology: percentage of soluble lignin, percentage of insoluble lignin, CBH and total height. Overlapping QTLs regions were detected, and these, can be the result of major genes involved in the regulation and control of the growth traits by epistatic interactions. In order to evaluate the effect of early selection using RAPD molecular data, molecular markers adjacent to QTLs were used genotype selection. The analysis of selection differential values suggests that for all the traits the phenotypic selection at seven years should generate larger genetic gains than early selection assisted by molecular markers and the combination of the strategies should elevate the selection efficiency.
\end{abstract}

Keywords: Genetic Mapping, Eucalyptus spp., QTL, RAPD, Wood quality.

\section{MAPEAMENTO DE QTLS PARA CARACTERÍSTICAS DE QUALIDADE DA MADEIRA E CRESCIMENTO EM HÍBRIDOS (Eucalyptus grandis X Eucalyptus urophylla)}

\begin{abstract}
RESUMO-O presente trabalho teve como objetivos a caracterização e identificação de QTLs para características de crescimento e de qualidade da madeira em híbridos de eucalipto derivados do cruzamento entre $\mathrm{E}$. grandis $e$ E. urophylla. Para isso foi desenvolvido um mapa de ligação $R A P D$ pouco saturado $(L O D=3$ e $r=0,40)$ contendo 52 marcas e 12 grupos de ligação. Características de qualidade da madeira e características de crescimento foram avaliadas quanto à presença de QTLs. Foram utilizadas metodologias de mapeamento por marca simples, mapeamento por intervalo simples e mapeamento por intervalo composto para posicionamento e caracterização dos efeitos dos QTLs. Todas as análises geraram resultados consistentes que indicaram a existência de QTLs relacionados com a expressão das características densidade, rendimento de polpa e teor de extrativos confirmados pela metodologia de mapeamento por intervalo simples e pelo mapeamento por
\end{abstract}

\footnotetext{
${ }^{1}$ Recebido em 31.10.2005 e aceito para publicação em 13.09.2006.

${ }^{2}$ Universidade Federal de Viçosa - BIOAGRO/Instituto de Biotecnologia Aplicada a Agropecuária - Rua P. H. Rolph, s/n, 36570-000 Viçosa-MG, Brasil.

${ }^{3}$ CENIBRA CELULOSE S/A - 35.196-000 Belo Orient- MG, Brasil. Rodovia BR 381 - km 172 - Distrito de Perpétuo Socorro, Brasil.
} 
intervalo composto e, ainda, outras regiões de menor significância confirmadas apenas pela metodologia de mapeamento por intervalo composto (teor de lignina solúvel, teor de lignina insolúvel, DAP e altura total). A sobreposição de QTLs em determinadas regiões dos grupos de ligação pode ser resultado da existência de regiões do genoma mais importantes para o crescimento e desenvolvimento da planta, indicando a existência de blocos gênicos de maior efeito relacionados com a regulação e controle das características estudadas. Visando comparar o efeito da seleção assistida, marcadores moleculares adjacentes aos QTLs detectados foram considerados como critério para a seleção individual. A comparação dos valores dos diferenciais de seleção evidenciou que a seleção fenotípica aos 7 anos resulta em ganhos superiores à seleção precoce e a combinação das duas estratégias deve contribuir para um aumento na eficiência dos métodos de seleção.

Palavras-chave: Mapeamento Genético, Eucalyptus spp., QTL, RAPD, Qualidade da madeira.

\section{INTRODUCTION}

At present, the most used species for reforestation projects in Brazil belong to the genus Eucalyptus (Myrtaceae) that stands out for the fast growth, easy management and good technological characteristics (TURNBULL, 1999). The growing interest for Eucalyptus wood can be sensed on the increase of the cultivated area with more than three million hectares between 1985 and 1994 and on the number of breeding programs aiming to obtain better raw material. Brazil has the second largest area of Eucalyptus forest settlements in the world, and it also stands out in the world market as one of the largest short-fiber cellulose producers (ALFENAS et al., 2004).

To assist the high demand for quality raw material for paper and cellulose production, technological characteristics of the wood are nowadays a priority in forest improvement programs (CAMPINHOS, 1999). Studies on wood technological characteristics are usually limited by the evaluation process, which can only be accomplished in adult plants and in laboratories with a good infrastructure. The application of modern measuring techniques, such as infrared absorption, allows the automation of the wood quality evaluation process (ANTTI, 1999). Analysis automation has been a decisive factor for genetic studies of wood quality considering the high number of individuals that should be evaluated.

The development of molecular marker techniques provided new resources to the traditional breeding and increased the importance of genetic mapping to improvement programs due to its feasibility and discrimination capacity of countless markers (ROCHA et al., 2003; JAUHAR, 2000). Among the populations of widespread use for genetic mapping of plants, the most outstanding are F2 populations derived from F1 by coupling or repulsion, populations obtained by backcrossing, R.I.L, double haploid and F1 populations of mixed segregation (GRATTAPAGLIA e SEDEROFF, 1994).

Strategies that require few generations provide remarkable time gains for species with long life cycles, such as forest species (GRATTAPAGLIA et al., 1996). In this scenario, the majority of the forestry mapping research uses populations that need few generations to be obtained associated with field data, aiming to select the sibs with prominent genetic variability for the target traits. Grattapaglia and Sederoff (1994), suggest the use of $\mathrm{F} 1$ populations derived from crosses of genetically contrasting genitors. This strategy makes use of the high genetic variability among genitors to obtain markers that are similar to those of a testcross. (ROCHA et al., 2004, GRATTAPAGLIA e SEDEROFF, 1994).

Among the available molecular marker techniques, the PCR based reactions (Polymerase Chain Reaction) stand out for the great production of DNA molecules amount from few initial ones. A PCR technique variant was described by two independent groups and almost at the same time (WELSH et al., 1990; WILLIAMS et. al., 1990) using arbitrary primers, not requiring previous knowledge of the target sequence to be amplified. Molecular marker analysis allows to identify genome segments that contributes to the genetic variance of a trait and thus to select superior genotypes. Selecting for favorable effects based on marker data (markerassisted selection, MAS) therefore has great potential for improving quantitative traits. The RAPD methodology is used for QTL detection in different plant species, 
because it facilitates high genome covering, with fast results and universal use (GRATTAPAGLIAe SEDEROFF, 1994; ROCHA et al., 2002). The main limitation of this technique lies on the questionable repeatability among laboratories and the low content of information per locus.

The term QTL (“Quantitative trait loci”), as defined by Geldermann 1975, bases on the existence of related loci of higher importance for the expression of quantitative traits. The use of molecular marker genetic maps for the study of the inheritance of quantitative traits allows the detection of chromosomes or linkage groups regions and that are more significant to the trait expression (SCHUSTER e CRUZ, 2004). Several QTLs related with development traits are described for species of the Eucalytus genus (JUNGHANS et al., 2003; THAMARUS et al., 2002; GRATTAPAGLIA et al., 1995; GRATTAPAGLIA et al., 1996; MARQUES et al., 1999; VERHAEGEN et al., 1997; BYRNE et al., 1997a,b).

The objectives of the present work were to detect candidate loci for QTLs related to growth and wood quality.

\section{MATERIALAND METHODS:}

\subsection{Plant Material}

The experimental material consisted of 90 E. grandis $\mathrm{x}$ E. urophylla elite hybrids from the CENIBRA CELULOSE S/A progeny tests located in the municipal district of Ipatinga, Minas Gerais, which presents the following characteristics: latitude $18^{\circ} \mathrm{S}$, longitude $42^{\circ}$ $\mathrm{W}, 800-1000$ meters above the sea level, precipitations at $1300-1500 \mathrm{~mm} /$ year and hydric deficit from 100 to $150 \mathrm{~mm} /$ year.

\subsection{Traits measured}

The growth traits circumference at breast height (CBH), total height, and commercial height were measured in 90 standing trees that had their leaves collected for DNA amplification. Three thick wood disks of 4 to $5 \mathrm{~cm}$ collected at breast height were sampled for measuring the following wood quality traits: wood density, cellulose pulp yield, percentage of extractives, percentage of insoluble lignin, percentage of soluble lignin, using a near infrared spectrophotometer - NIRS. The wood disks were ground in a hurricane-type mill and separated using $0.5 \mathrm{~mm}$ sieves.

\subsection{RAPD marker genotyping}

Leaf samples were used in the DNA extraction as described by Doyle and Doyle (1990) with the following modifications: $1 \%$ insoluble P.V.P. (polyvinylpyrrolidine) and $0.4 \%$ de $\beta$-mercaptoethanol in the extraction buffer. The RAPD amplifications were performed according to Williams et al., (1990). A total of 260 random primers (Operon Technologies Inc., Alameda, CA) were used to select the ones suitable for mapping.

\subsection{Mapping approach}

Marker segregation ratio was evaluated using the $\chi^{2}$ test ( $\alpha=0.01$ level). The linkage analysis for RAPD marker data was carried out for each parental data set using the GQMOL software developed at the Universidade Federal de Viçosa (SCHUSTER e CRUZ, 2004) available at http://www.ufv.br/dbg/gqmol/ gqmol.htm. Markers linked with a recombination frequency of $\theta \leq 0.40$ and $P \leq 0.0001$ were assigned to the linkage groups. The Kosambi map function was used to convert the recombination frequency data into genetic distances.

\subsection{QTL mapping - Single-factor analysis}

Single-marker variance analysis $(\mathrm{P}<0.05)$ was performed to identify QTLs associated with wood quality and growth traits using the GQMOL software. This procedure allows the marker effect evaluation even if it is not included in the linkage map.

\subsection{QTL mapping - Composite interval mapping}

To better estimate the number and position of the QTLs and verify the results obtained using singlefactor ANOVA, the association markers QTLs were also evaluated by composite interval mapping. This procedure used both QTL Cartographer version 1.14 (BASTEN et al., 2000) and GQMOL. The option model 6 of the Zmapqtl with 10 background parameters based on forward-backward regression analysis and $1 \mathrm{cM}$ walking speed were used. To determine an empirical threshold significance level for QTL detection 1,000 permutations were performed considering the significance levels of $5 \%$ and $10 \%$ (CHURCHILL e DOERGE, 1994).

\subsection{Assisted selection}

In order to evaluate the effect of early selection using RAPD molecular data, molecular markers adjacent

R. Árvore, Viçosa-MG, v.31, n.1, p.13-24, 2007 
to QTLs were used to select genotypes among the evaluated population. Differential selection values of assisted and phenotypic selection were used as reference values for selection strategy efficiency.

\section{RESULTS AND DISCUSSION}

\subsection{Polymorphism detection and selection of RAPD primers}

Although more robust molecular marker techniques, such as the microsatellites markers (BRONDANI et al., 1998; 2002), are described for Eucalyptus, the availability of numerous RAPD primers was decisive for the development of this work. Previously, RAPD primers were tested to detect polymorphic DNA fragments for the genetic mapping. Two hundred and sixty decamers primers, with arbitrary sequences from kits A, B, C, D, F, G, H, I, J, K, L, N, P, Q, R, V, W, X, $\mathrm{Z}$ (Operon Technologies Inc., Boulevard, CA, USA) were evaluated. Sixty-three primers were selected resulting in a total amplification of 176 polymorphic DNA fragments with Mendelian segregation (1:1) and sizes varying from 200 to 2,000 base pairs. Of these, 63 markers were discarded due to the few genotypes amplified by them. A RAPD pattern using primer OPK 16 is shown in Figure 1.

Seeking future map comparisons, primers used to amplify markers already mapped by other authors were tested (VERHAEGEN e PLOMION, 1996; GRATTAPAGLIA e SEDEROFF, 1994). Such primers did not generate polymorphisms similar to those described in the literature and produced other polymorphic fragments not described previously (data not show). The discrepancy in comparison to the maps already developed indicates that the RAPD genetic linkage maps are only valid for the mapped populations and populations related with them. The distortions between maps can be the results of different factors, standing out the high genetic diversity characteristic of the genus Eucalyptus; the high sensitivity of RAPD methodology and the use of hybrids between two different species for mapping. Campinhos (2005) noticed distortions between RAPD linkage maps obtained from the cross of an E. grandis parent previously mapped with $5 E$. urophylla parents, such as, fusion of distinct linkage groups, inversion of mapping order, lack of linkage between markers previously mapped and differences in the recombination frequencies between adjacent markers.

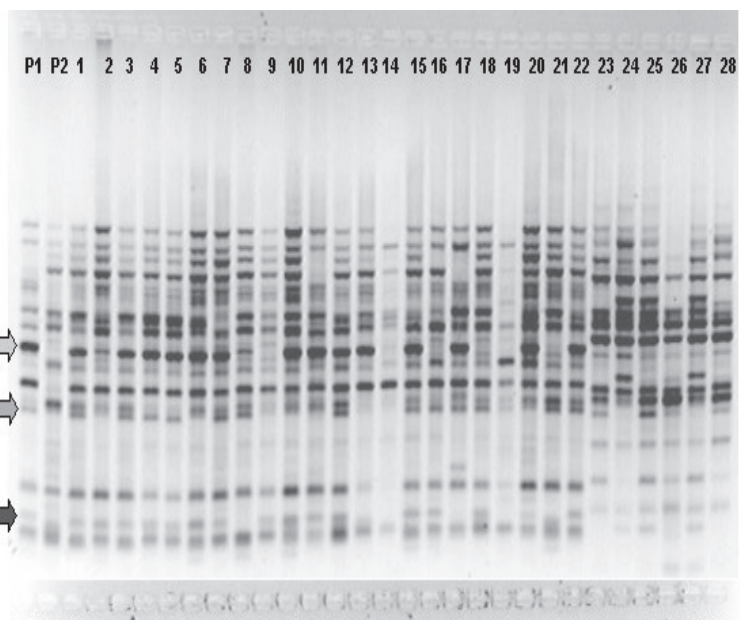

2930313233 34 $353637383940414243444546 \quad 47484950515253 \quad 5455565758$
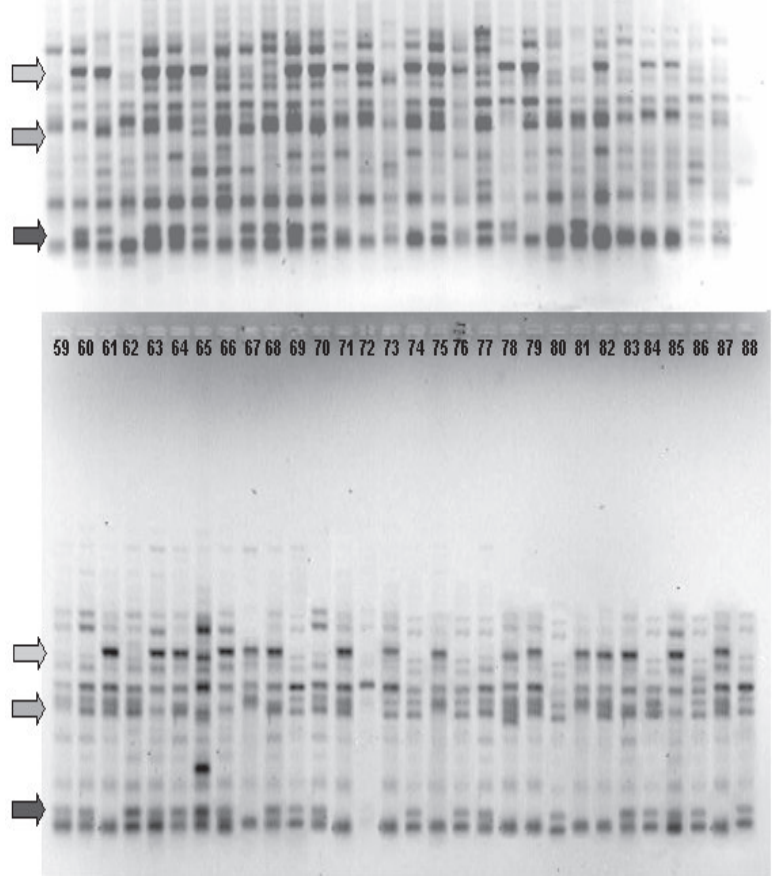

Figure 1 - RAPD amplification using primer OPK16.

Figura 1 -Eletroforese em gel de agarose 1,5\% da reação de amplificação utilizando o oligonucleotídeo OPK16. P1 e P2 mostram o padrão de amplificação dos genitores E. grandis e E. urophylla, seguidos da amplificação de 88 irmãos-completos F1 (1 a 88). As setas indicam fragmentos de DNA de segregação $1: 1$. 


\subsection{Construction of linkage map}

Prior to map construction, RAPD marker segregation was tested using the chi-square test $(\mathrm{P}<0.05)$. From a total of 113 markers, 15 (13.2\%) presented distorted segregation. It is expected that on average two markers would show distortion from the expected proportion $(\alpha<0.01)$. The elimination of markers with distorted segregation is a possibility that should be evaluated considering the causes of such distortions such as, the insufficient number of individuals assayed (ROCHA et al., 2004; CARLSON et al., 1991), amplification of overlapping markers by RAPD, error during marker evaluation (CAMPINHOS et al., 2005) and natural or artificial selection of seedlings in the greenhouse (VERHAEGEN e PLOMION, 1996). In addition, the high genetic load of the species belonging to the Eucalyptus genus can result in distortion of markers close to lethal genes in heterozygous condition (YOUNG et al., 2000).

The proportion of distorted segregation for markers was comparable with those reported for E. grandis $\mathrm{x}$ E. urophylla hybrid mapping: Campinhos (2005), 13.7\%; Verhaegen and Plomion (1996); 7\%, Grattapaglia and Sederoff (1994), 4\%, and Byrne et al. (1995) working with E. nitens, 6\%. Markers presenting distorted segregation were not excluded of the following analyses and are marked with an asterisk in the map (markers E19c_550 and E19d_460 in linkage group 5).

Interspecific hybrid mapping allows the construction of two linkage maps, one for each parental origin. Such procedure brings the advantage of a reference map development for the parental species. Many works used this strategy for the construction of specificspecies maps (VERHAEGEN e PLOMION, 1996; GRATTAPAGLIA e SEDEROFF, 1994; BYRNE et al., 1995). However, considering the limited number of markers amplified in this work and the nature of the molecular technique used, of difficult reproducibility, only one map for the hybrid population was considered to assisted selection purposes.

Twelve slightly saturated linkage groups comprising 51 linked markers, as well as 62 non-linked markers were obtained (Figure 2). The high number of nonlinked markers is probably due the impossibility of obtaining linkage estimates between heterozygous markers of different parental origins, which results on an underestimated number of linked markers.
Markers were identified using the primer nomenclature followed by a lowercase letter, related with the number of markers amplified per primer. The size of the DNA fragment in base-pairs estimated by the GQMOL software is indicated. The total size of the map was $632 \mathrm{cM}$ with a $16.14 \mathrm{cM}$ average distance between loci, with $3.08 \mathrm{cM}$ minimum distance value between two adjacent marks and $32.08 \mathrm{cM}$ maximum distance. Grattapaglia et al., 1994, estimated the genome length of E. grandis and E. urophylla in Centi-Morgans (cM) units using the RAPD technique in a "pseudotestcross" sib of 62 individuals (E. grandis genome length $-1620 \mathrm{cM}$ and E. urophylla -1156 $\mathrm{cM})$. Considering the hybrid genome length as a mean of these two values $(1388 \mathrm{cM})$, the estimated hybrid map coverage of the eucalyptus's genome is $45.5 \%$.

\subsection{Quantitative traits}

Taking into consideration that trait non-adjustment to the normal distribution results in lower precision of QTL detection, the trait normality was evaluated using Lilliefors test as well as symmetry and curtose estimates. Total and commercial heights presented the highest deviation from the normal distribution leading to rejection of the hypothesis at $1 \%$ probability (Table 1). Though these variables were not discarded from the analyses since the QTLs detection tests used are considered robust enough to support the observed deviation from the normality (SCHUSTER e CRUZ, 2004).

In addition to data normality, the correlations between the assayed metric traits were taken into account in order to detect pleiotropic effects (Table $2)$. High negative correlation values between the traits extractive contents $x$ pulp yield and insoluble lignin x pulp yield indicate good data quality obtained by NIR absorbance readings. The correlation values between the traits DAP and height were positive and high, as expected.

Although the trait heritability estimates are of major importance for the study of QTLs, these estimates for wood quality and growth could not be obtained because the assayed hybrid parents were 15 years old preventing the comparison with the 7-year-old hybrids. However, the high heritability values usually found for wood quality traits assisted selection procedures (ZOBEL e JETT, 1995). 
ROCHA, R.B. et al.
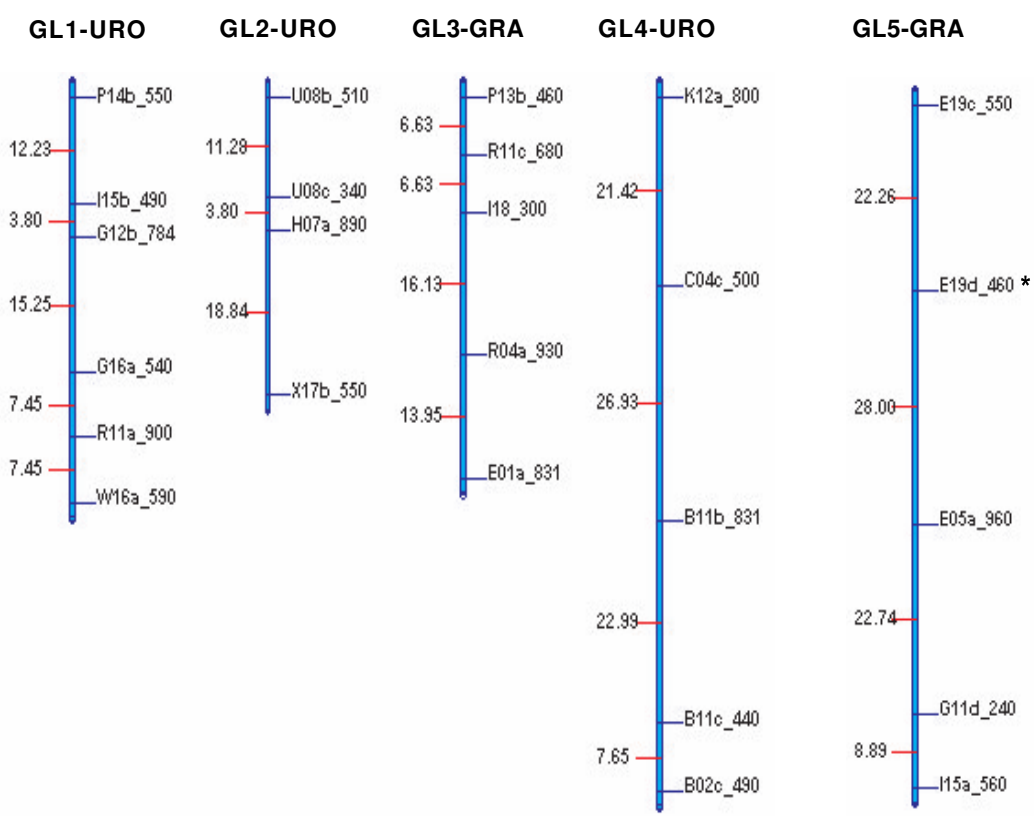

\section{GL6-GRA}

GL7-URO

GL8-URO

GL9-GRA

GL10-GRA

GL11-URO

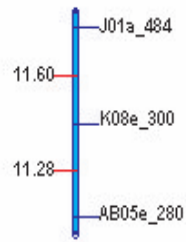
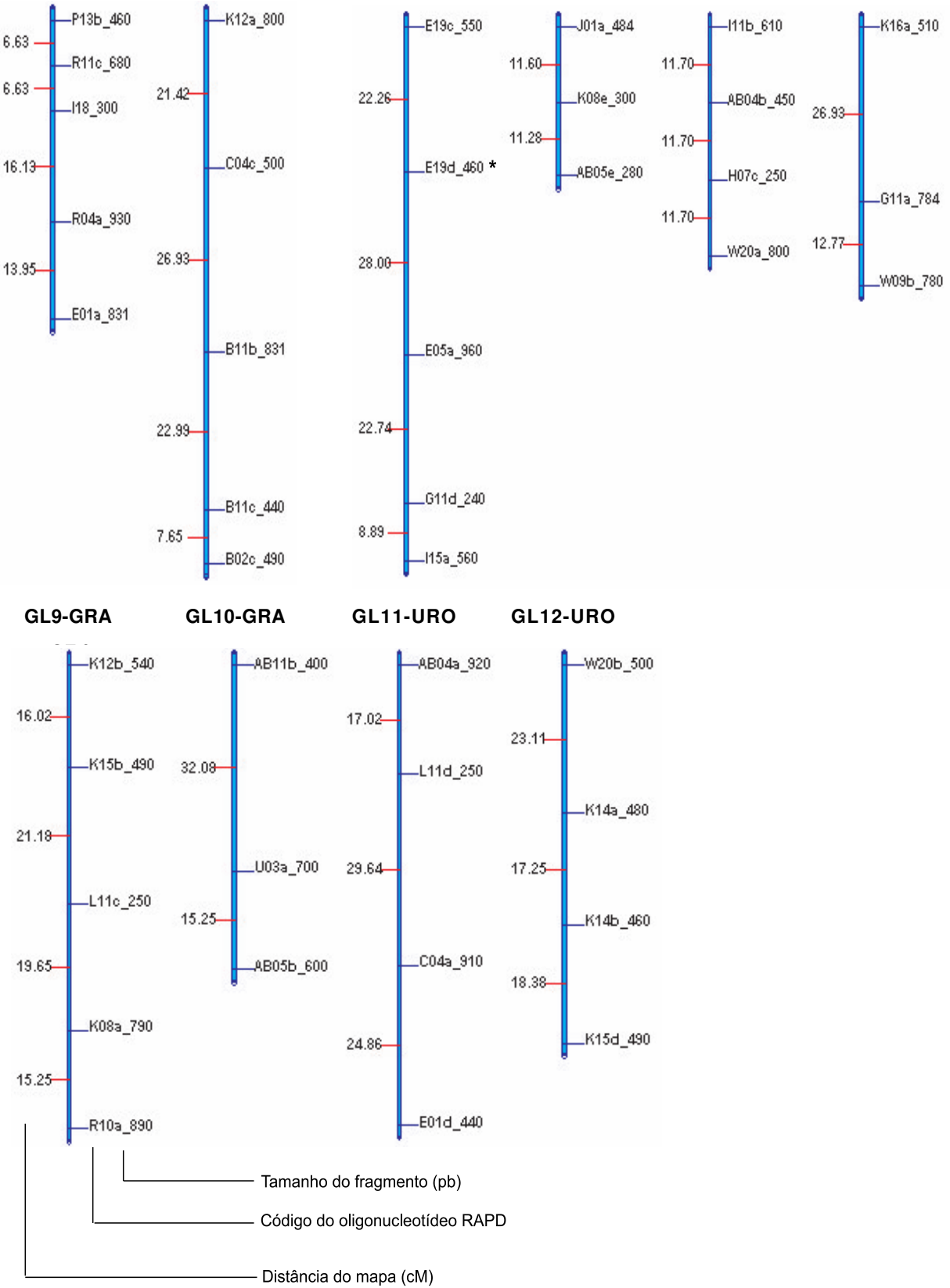

Figure 2 - Genetic map of Eucalyptus developed using RAPD data with 90 hybrids between Eucalyptus grandis and Eucalyptus urophylla with $\mathrm{LOD}=3 \mathrm{e} r=0,40$ and Kosambi map function. The parental origin is showed together with the linkage group identification.

Figura 2 - Mapa genético de Eucalyptus desenvolvido a partir da análise de 90 híbridos do cruzamento Eucalyptus grandis e Eucalyptus urophylla. Os grupos de ligação foram obtidos utilizando-se valores de $L O D=3$ e $r=0$, 40 e unidade de Kosambi. Os valores da esquerda representam as distâncias entre as marcas e os da direita estão identificando as marcas. Estão assinaladas com um asterisco as marcas que apresentaram segregação distorcida segundo o teste de $\chi^{2}$ com $a=5 \%$. A origem parental está mostrada junto com a identificação do grupo de ligação.

R. Árvore, Viçosa-MG, v.31, n.1, p.13-24, 2007 
Table 1 - Lilliefors statistic values for the assayed quantitative traits

Tabela 1 - Valores das estatísticas de Lilliefors para as características quantitativas avaliadas

\begin{tabular}{llcc}
\hline Traits & Lilliefors Statistics & Symmetry & Curtose \\
\hline Density Kg/m & $\mathrm{D}_{\text {(calculated) }}=0.0395 \mathrm{~ns}$ & -0.192 & 3.18 \\
Pulp Yield \% & $\mathrm{D}_{\text {(calculated) }}=0.0787 \mathrm{~ns}$ & -0.34 & 5.45 \\
Extractive contents \% & $\mathrm{D}_{\text {(calculated) }}=0.1029 *$ & 1.315 & 6.119 \\
Insoluble lignin level \% & $\mathrm{D}_{\text {(calculated) }}=0.0589 \mathrm{~ns}$ & -0.445 & 4.144 \\
Soluble lignin level \% & $\mathrm{D}_{\text {(calculated) }}=0.0544 \mathrm{~ns}$ & 0.229 & 5.494 \\
DAP cm & $\mathrm{D}_{\text {(calculated) }}=0.0758 \mathrm{~ns}$ & -0.183 & 2.184 \\
Total height m & $\mathrm{D}_{\text {(calculated) }}=0.1235 * *$ & -1.7218 & 6.734 \\
Commercial height $\mathrm{m}$ & $\mathrm{D}_{\text {(calculated) }}=0.1122 * *$ & -1.448 & 5.222 \\
\hline
\end{tabular}

$\mathrm{D}$ (table) $10 \%=0,0849 \quad \mathrm{D}($ table) $5 \%=0,0936 \quad \mathrm{D}($ table $) 1 \%=0,1087$

If Dcalc. > Dtab. Ho rejection: It is acceptable to consider data following normal distribution.

$*$ Significant at $5 \%$, ** significant at $1 \%$, ns non significant.

Table 2 - Pearson correlation values for growth and wood quality metric traits. Correlations greater than $50 \%$ are in bold Tabela 2 - Valores de correlações de Pearson para características métricas de crescimento e qualidade da madeira. Magnitudes de correlação maiores que 0,50 estão em negrito

\begin{tabular}{|c|c|c|c|c|c|c|c|c|}
\hline & Density & $\begin{array}{l}\text { Pulp } \\
\text { Yield } \\
\end{array}$ & Extractive & $\begin{array}{c}\text { Insoluble } \\
\text { lignin }\end{array}$ & $\begin{array}{l}\begin{array}{c}\text { Soluble } \\
\text { lignin }\end{array} \\
\end{array}$ & $\overline{\text { DAP }}$ & $\begin{array}{c}\text { Total } \\
\text { Height } \\
\end{array}$ & $\begin{array}{c}\text { Commercial } \\
\text { height }\end{array}$ \\
\hline Density & 1 & & & & & & & \\
\hline Pulp Yield & -0.11463 & 1 & & & & & & \\
\hline Extratives & 0.101007 & -0.80359 & 1 & & & & & \\
\hline Insoluble lignin & 0.12746 & -0.68508 & 0.364777 & 1 & & & & \\
\hline Soluble lignin & -0.18718 & 0.31799 & -0.43311 & -0.22105 & 1 & & & \\
\hline D.A.P & 0.398862 & 0.078967 & -0.29154 & 0.183714 & 0.050692 & 1 & & \\
\hline Total height & 0.336004 & 0.374547 & -0.43589 & -0.06478 & 0.190059 & 0.78087 & 1 & \\
\hline $\begin{array}{l}\text { Commercial } \\
\text { Height }\end{array}$ & 0.349215 & 0.325152 & -0.44712 & -0.00936 & 0.16451 & 0.843917 & 0.96556 & 1 \\
\hline
\end{tabular}

\subsection{QTL Mapping}

Prior to other QTL analysis a single factor analysis was carried out using ANOVA and regression procedures for detecting markers related with expression of the characteristics independent with their position in the linkage groups. Fifty-three markers related with QTLs loci were found, 22 positioned in the map and 31 nonclustered markers (Table 3 ). The high number of nonlinked markers obtained increases the importance of the single factor mapping approach, indicating the existence of key genome regions for the expression of traits that was not mapped in this study. Verhaegen et al. (1997) found at least four genome regions in $E$. urophylla and five regions in E. grandis related with the traits growth, height and diameter. Grattapaglia et al. (1996) found three regions in different linkage groups which were important for the expression of the traits DAP and wood density.

The methodologies of simple and composed interval
(LANDER e BOTSTEIN, 1989; ZENG, 1993) were also used to detect QTL's position along the linkage groups and to increase the precision of effect and position estimates. Some QTLs, which were apparently not significant by the simple interval methodology, presented LR values superior to the established by the permutation test (data not shown). This is an expected result, since the mapping methodology of composite interval associated with permutation tests assures an increased power to QTL detection (ZENG, 1993). The threshold value for the QTL significance was determined by permutation test (DEORGE e CHURCHILL, 1996) making use of 1000 permutations and 5\% significance level for the complete genome (Table 4).

A total of nine QTLs were identified: one QTL for density, one QTL for pulp yield and two QTLs for extractive contents validated by the two methodologies, and also one QTL for soluble lignin level, two QTLs for insoluble lignin level, one QTL for DAP and one QTL for total height detected only by the composed 
ROCHA, R.B. et al.

interval mapping methodology (Table 4). Two adjacent QTLs for extractive contents were detected by composite interval mapping in different positions from those obtained by the simple interval mapping method characterizing a "ghost" QTL resulted from the sum of the effects of two adjacent QTLs present in the same linkage group.

High correlation values associated to QTLs located next to each other could be the indication of a gene block of pleiotropic effect capable of affecting the simultaneous expression of one or more traits. Although a high negative correlation value has been found between extractive contents and pulp yield traits, there is no indication that these traits are controlled mainly by common gene blocks, considering that larger effect
QTLs found for each trait are in different linkage groups.

On the other hand, the high negative correlation value found between the traits insoluble lignin level and pulp yield associated to overlapping QTLs found in the linkage group 3 suggests that these traits have the expression affected by common gene blocks. Grattapaglia et al. (1996) also reported the existence of key genomic regions, widely related with the expression of the traits growth and wood quality. This could be due to the existence of larger genes effect not only related with regulation and control of the traits assayed but also with the predominantly epistatic effect. Within this context, all the linkage group 1 and the regions over $20 \mathrm{cM}$ in the linkage group 3 stand out as determinant of plant growth and development.

Table 3 - Mapping results using ANOVA and regression single factor analysis

Tabela 3 - Resultados do mapeamento por marca simples utilizando as metodologias de análises de variância e de regressão, mostrando as marcas ligadas aos QTLs e as diferenças entre as médias dos indivíduos que apresentam a marca (1) e os que não apresentam (O). Os grupos de ligação das marcas estão indicados

\begin{tabular}{|c|c|c|c|c|c|c|c|}
\hline Marker & Prob.(F) & $\mathrm{R}^{2}$ & G. L. & Marker & Prob.(F) & $\mathrm{R}^{2}$ & G. L. \\
\hline \multicolumn{4}{|c|}{ Density } & \multicolumn{4}{|c|}{ Soluble lignin level } \\
\hline $\mathrm{ACO} 03 \mathrm{~b}$ & $0.035 *$ & 0.3563 & NA & AB04b_450 & $0.0282 *$ & 0.3557 & 7 \\
\hline E05a_960 & $0.0257 *$ & 0.3762 & 5 & E19e & $0.0272 *$ & 0.3668 & NA \\
\hline$X 17 b \_550$ & $0.0054 * *$ & 0.2753 & 2 & G12a & $0.0497 *$ & 0.3862 & NA \\
\hline K01a & $0.0353 *$ & 0.2932 & NA & P14a_700 & $0.0324 *$ & 0.363 & NA \\
\hline B02c_490 & $0.0178 *$ & 0.2795 & 4 & B06d & $0.0317 *$ & 0.2765 & NA \\
\hline \multicolumn{4}{|c|}{ Pulp yield } & G19a & $0.0337 *$ & 0.3005 & NA \\
\hline AF $15 a$ & $0.0018 * *$ & 0.2902 & NA & I $11 \mathrm{a}$ & $0.0075 * *$ & 0.2548 & NA \\
\hline E01a_831 & $0.0033 * *$ & 0.3421 & 3 & \multicolumn{4}{|c|}{ DAP } \\
\hline U03c_250 & $0.0303 *$ & 0.3663 & NA & AD $18 b$ & $0.0435 *$ & 0.3731 & NA \\
\hline $\mathrm{AB} 05 \mathrm{c}$ & $0.0327 *$ & 0.3004 & NA & B11b_831 & $0.0415 *$ & 0.3749 & 4 \\
\hline G16a_540 & $0.0294 *$ & 0.2967 & 1 & B11d_240 & $0.0426 *$ & 0.3485 & NA \\
\hline C14 & $0.0292 *$ & 0.2956 & NA & $\mathrm{B} 15 \mathrm{~b}$ & $0.0135 *$ & 0.3483 & NA \\
\hline G19a & $0.0092 * *$ & 0.26 & NA & C04c_500 & $0.003 * *$ & 0.3316 & 4 \\
\hline R04a_930 & $0.0327 *$ & 0.3702 & 3 & E19d_460 & $0.0166 *$ & 0.3517 & 5 \\
\hline \multicolumn{4}{|c|}{ Extractive contents } & $\mathrm{J} 07 \mathrm{~b}$ & $0.0493 *$ & 0.3745 & NA \\
\hline B11d_240 & $0.0234 *$ & 0.3316 & NA & AB02a_800 & $0.0457 *$ & 0.3123 & NA \\
\hline E01a_831 & $0.0176 *$ & 0.3713 & 3 & $\mathrm{AB} 15 \mathrm{a}$ & $0.018 *$ & 0.264 & NA \\
\hline $\mathrm{K} 12 \mathrm{~d}$ & $0.0424 *$ & 0.3667 & NA & G16a_540 & $0.0442 *$ & 0.3111 & 1 \\
\hline G16a_540 & $0.0005 * *$ & 0.1944 & 1 & X17b_550 & $0.0481 *$ & 0.3617 & 2 \\
\hline $\mathrm{C} 14 \mathrm{a}$ & $0.028 *$ & 0.2942 & NA & \multicolumn{4}{|c|}{ Commercial height } \\
\hline R11a_900 & $0.0062 * *$ & 0.2504 & 1 & AF $15 b$ & $0.0439 *$ & 0.3453 & NA \\
\hline W16a_590 & $0.0313 *$ & 0.2989 & 1 & C04c_500 & $0.0085 * *$ & 0.3499 & 4 \\
\hline \multicolumn{4}{|c|}{ Insoluble lignin level } & E01b & $0.026 *$ & 0.3343 & NA \\
\hline AF $15 a$ & $0.0014 * *$ & 0.2855 & NA & E01e & $0.0162 *$ & 0.3564 & NA \\
\hline AI $15 b$ & $0.0498 *$ & 0.3707 & NA & K12a_800 & $0.0486 *$ & 0.3836 & 4 \\
\hline E01a_831 & $0.025 *$ & 0.3782 & 3 & G16a_540 & $0.0101 *$ & 0.2638 & 1 \\
\hline G12b_784 & $0.0288 *$ & 0.3678 & 1 & R11a_900 & $0.0266 *$ & 0.2934 & 1 \\
\hline G12f_260 & $0.0026 * *$ & 0.3274 & NA & & & & \\
\hline $\mathrm{K} 16 \mathrm{c}$ & $0.0372 *$ & 0.3728 & NA & & & & \\
\hline R10c_280 & $0.0171 *$ & 0.2732 & NA & & & & \\
\hline G19a & $0.0142 *$ & 0.2727 & NA & & & & \\
\hline
\end{tabular}

R. Árvore, Viçosa-MG, v.31, n.1, p.13-24, 2007 
Table 4 - Results for composite interval mapping

Tabela 4 - Detecção de QTLs relacionados com a expressão das características avaliadas utilizando-se as metodologias de mapeamento por intervalo simples $(A)$ e mapeamento por intervalo composto $(B)$

\begin{tabular}{lcccccc}
\hline Trait & $\begin{array}{c}\text { Linkage } \\
\text { group }\end{array}$ & $\begin{array}{c}\text { QTL } \\
\text { position }\end{array}$ & $\begin{array}{c}\text { Critic } \\
\text { LR }\end{array}$ & $\begin{array}{c}\text { Maximum } \\
\text { LR }\end{array}$ & $\begin{array}{c}\text { Adjacent } \\
\text { markers }\end{array}$ & $\begin{array}{c}\text { Part of } \\
\text { variation explained }\end{array}$ \\
\hline Density & 2 & 29.7 & 11.29 & 13.05 & X17b_550 e H07a_890 & $29.4 \%$ \\
Pulp Yield & 3 & 43.3 & 12.25 & 18.86 & E01a_831 e R04a_930 & $13.5 \%$ \\
Extractive contents & 1 & 14.9 & 11.34 & 14.84 & I15b_490. G12b_784 & $17.3 \%$ \\
& 1 & 31.5 & 11.34 & 15.77 & G16a_540 e R11a_900 & $24.8 \%$ \\
Insoluble lignin level & 1 & 16.2 & 11.32 & 11.34 & R04a_930 e E01a_831 & $12.3 \%$ \\
& 3 & 43.3 & 11.32 & 13.15 & I15b_490. G12b_784 & $14.1 \%$ \\
Soluble lignin level & 7 & 12 & 11.22 & 11.22 & AB04b_450 e H07c_250 & $18.1 \%$ \\
DAP & 4 & 32.4 & 12.13 & 12.14 & C04c_500 e B11b_831 & $20.0 \%$ \\
Commercial height & 4 & 32.4 & 11.15 & 14.94 & C04c_500 e B11b_831 & $19.8 \%$ \\
\hline
\end{tabular}

In view of the high positive correlation found between the commercial traits height and DAP associated with overlapping QTLs found in the linkage group 4, it is also likely that these traits have the expression affected by common gene blocks. The high correlation value and the similarity of interval mapping methodologies suggest the existence of a unique QTL related with the expression of these two traits.

\subsection{Assisted selection}

The use of selection procedures assisted by molecular markers usually depends on two main steps: characterization of the effects and QTL identification and manipulation of these QTLs along the selection cycles (MOREAU et al., 1998). Selection procedures assisted by molecular markers usually present differential efficiency compared with phenotypic selection procedures and can be more or less efficient than the latter (YOUSEF e JUVIK, 2001). According to Lande e Thompson, (1990) the use of selection methodologies assisted by molecular markers should be decided on a case-by-case basis.

Table 5 - Values for selection differentials obtained from information of molecular markers and phenotypic values

Tabela 5 - Valores dos diferenciais de seleção obtidos pela seleção assistida por marcadores moleculares e pela seleção fenotípica dos genótipos

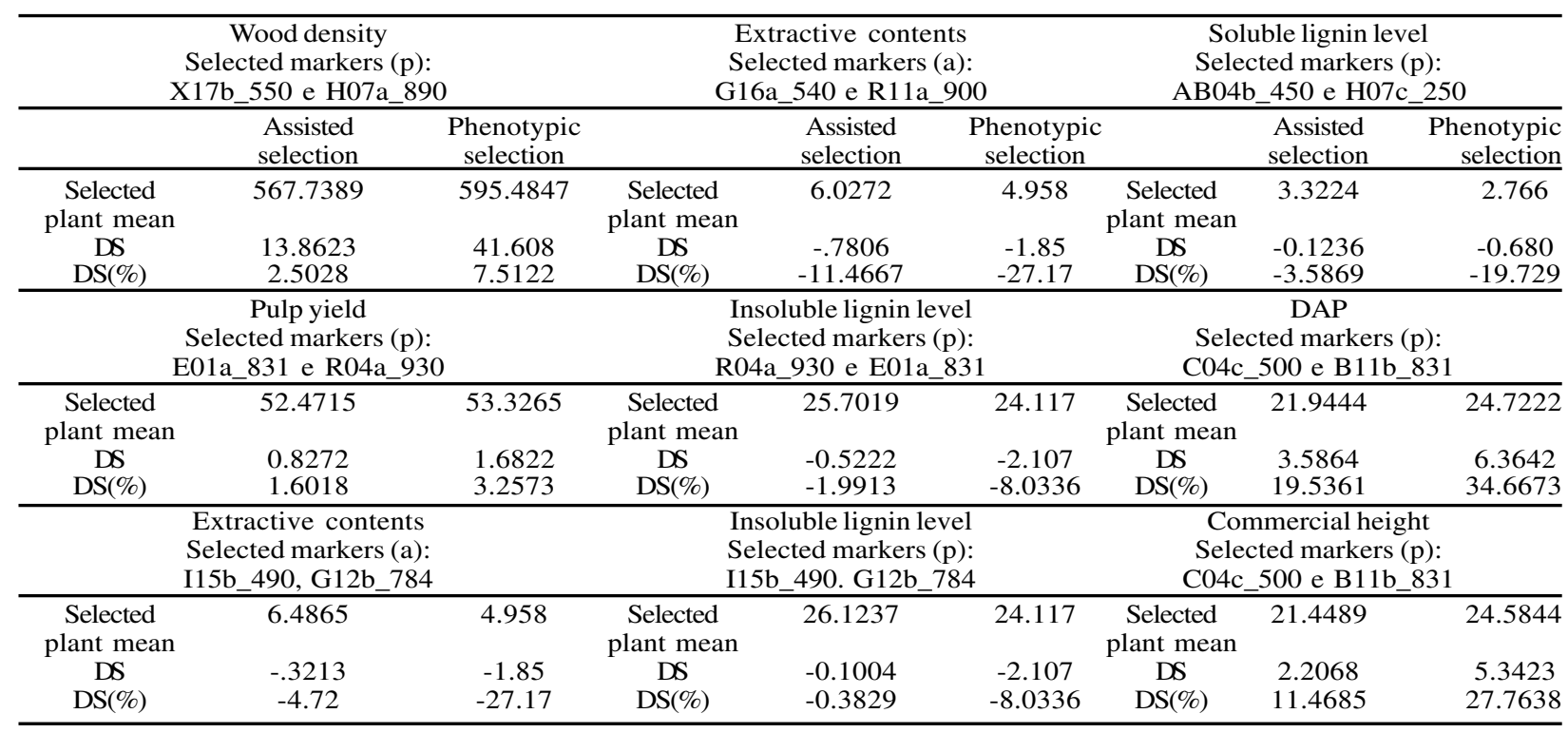


In order to evaluate the effect of early selection using RAPD molecular data, molecular markers adjacent to QTLs were used to select genotypes among the evaluated population. With this purpose, differential selection values of assisted and phenotypic selection procedures were compared (Table 5). The efficiency of selection procedures is directly proportional to the selection differential and therefore the methodology resulting in the largest selection differentials, in this case is considered the most efficient one. For obtaining the values of selection differential, the percentage of the selected plants considered was $10 \%$.

The analysis of selection differential values suggests that for all the assayed traits the phenotypic selection at seven years should generate larger genetic gains than early selection assisted by molecular markers. The QTL flanked by the markers I15b_490, G12b_784 identified only by the composite interval mapping methodology for insoluble lignin level presented the smallest effect on alteration in the mean trait $(0.3 \%)$.

QTLs identified only by the composite interval mapping methodology and not by the simple interval mapping represent regions of smaller effect than those identified by both methodologies and its use for procedures of assisted selection should be evaluated individually. However, traits mean alterations as high as $19 \%$ for DA.P and $11 \%$ for extractive contents and commercial height were found using selection markers.

\section{CONCLUSIONS}

The present work describe markers for assisted selection in the evaluated and related populations that should provide gains in the assisted early selection, although the development of theoretical mapping studies and more robust marker techniques shows that the evaluation of more individuals and the use of others molecular markers techniques, such as SSR, should also be considered.

\section{ACKNOWLEGMENTS}

We would like to thank CENIBRA CELULOSE S/A and CAPES for all support given to this work.

\section{REFERENCES}

\author{
ALFENAS A.C. et al. Clonagem e \\ doenças do Eucalipto. Viçosa, MG: \\ Editora UFV, 2004. 442p.
}

R. Árvore, Viçosa-MG, v.31, n.1, p.13-24, 2007
ANTTI, H. Multivariate characterization of wood related materials. 1999. $86 \mathrm{f}$. Tesis, University of Umea, Umea, 1999.

BASTEN, C.J.; WEIR, B.S; ZENG, Z.B. QTL Cartographer version 1.14. Raleigh: North Carolina State University, 2000.

BRONDANI, R.P.V. et al. Development, characterization and mapping of microsatellite markers in Eucalyptus grandis and E. urophylla. Theoretical and Applied Genetics, v.97, p.816-827, 1998.

BRONDANI, R.P.V.; BRONDANI C.; GRATTAPAGLIA D. Towards a genus-wide reference linkage map for Eucalyptus based exclusively on highly informative microsatellite markers. Molelucar Genetics Genomics, v.267, p.338-347, 2002.

BYRNE, M.; MURREL, J. C.; ALLEN, B. An integrated genetic linkage map for Eucalyptus using RFLP, RAPD and isozyme markers.

Theoretical and Applied Genetics, v.91, p.869-875, 1995.

BYRNE M. et al. Identification and mode of action of quantitative trait loci affecting seedling height an leaf area in Eucalytpus nitens. Theoretical and Applied Genetics, v.94, p.674-681, 1997a.

BYRNE M. et al. Mapping of quantitative trait loci influencing frost tolerance in Eucalyptus nitens. Theoretical and Applied Genetics, v.95, p.975-979, 1997b.

CARLSON J. E.; TULSIERAM L. K.; GLAUBITZ, J. C. Segregation of random amplified DNA markers in F1 progeny of conifers. Theoretical Applied Genetics, v.83, p.194-200, 1991

CAMPINHOS, E.N. et al. Localized mapping of RAPD markers in Eucalyptus grandis. Crop Breeding and Applied Biotechnology, v.5, n.1, p.91-98, 2005.

CAMPINHOS, E. Sustainable plantations of high-yield Eucalyptus trees for production of fiber: the Aracruz case. New Forests, v. 17 p.129-143, 1999.

R. Árvore, Vicosa-MG, v.31, n.1, p.13-24, 2007 
CHURCHILL G. A.; DOERGE W. Empirical threshold values for quantitative trait mapping Genetics, v.138, p.963-971, 1994

DEORGE, R. W., CHURCHILL, G. A. Permutation tests for multiple loci affecting a quantitative character. Genetics, v.142 p.285-294, 1996

DOYLE, J.J.; DOYLE, J.L. Isolation of plant DNA from fresh tissue. Focus, v.12, n.27, p. 13-15, 1990.

GELDERMANN, H. Investigations on inheritance of quantitative characters in animals by genes markers. Theoretical and Applied Genetics, v. 46, p.310-330, 1975.

GRATTAPAGLIA, D.; BERTOLUCCI, F.L.; SEDEROFF, R. Genetic mapping of quantitative trait loci controlling vegetative propagation in Eucalyptus grandis and $E$. urophylla using a pseudo-testcross strategy and RAPD markers. Theoretical and Applied Genetics, v.90, p.933-947, 1995.

GRATTAPAGLIA, D.; SEDEROFF, R. Genetic linkage maps of Eucalyptus grandis and $E$. urophylla using a pseudo-testcross mapping strategy and RAPD markers. Genetics, v.137, p.1121-1137, 1994.

GRATTAPAGLIA, D. et al. Genetic mapping of quantitative trait loci controlling growth trait and wood quality traits in Eucalyptus grandis using maternal half-sib family and RAPD markers. Genetics, v.144, p.1205-1214, 1996.

JAUHAR, P. P. Methods of genomes analysis in plants. Florida: C.R.C. Press, 2000. 386p.

JUNGHANS, D. T. et al. Resistance to rust (Puccinia psidii Winter) in Eucalyptus mode of inheritance and mapping of a major gene with RAPD markers. Theoretical Applied and Genetics, v.108, 175-180, 2003.

LANDE, R.; THOMPSON, R. Efficiency of marker assisted selection in the improvement of quantitative traits. Genetics, v.124, p.743-756, 1990.

LANDER, E. S.; BOTSTEIN, D., Mapping mendelian factors underlying quantitative traits using RFLP linkage maps. Genetics, v.121, n.1, p.185-199, 1989
MARQUES, C. M. et al. Genetic dissection of vegetative propagation traits in Eucalyptus tereticornis and E. globules. Theoretical and Applied Genetics, v.99, p.936-946, 1999.

MOREAU L. et al. Marker-assisted selection efficiency in populations of finite size.

Genetics, v.148, p.1353-1365, 1998.

ROCHA, R B. et al. Mapeamento genético no melhoramento de plantas. Biotecnologia Ciência e Desenvolvimento, v. 30, p.27-32, 2003.

ROCHA, R. B. et al. Comparisons of segregating populations for genetic mapping. Crop Breeding and Applied Biotechnology, v.4, p.408-415, 2004.

ROCHA, R. B. et al. Fingerprint and genetic diversity analysis of Eucalyptus spp. genotypes using RAPD and SSR markers, Scientia Forestalis, v.62, p.24-31, 2002.

SCHUSTER, I.; CRUZ, C. D. Estatística genômica aplicada a populações derivadas de cruzamentos controlados. Viçosa, MG: Editora UFV, 2004. 568p.

THAMARUS K. A. et al. A genetic linkage map for Eucalyptus globulus with canditade loci for wood, fibre and floral traits. Theoretical and Applied Genetics, v.104, p.379-387, 2002.

TURNBULL J. W., Eucalypt plantation. New Forests, v.17, p.37-52, 1999.

VERHAEGEN, D.; PLOMION, C. Genetic mapping in Eucalyptus urophylla and Eucalyptus grandis using RAPD markers. Genome, v.39, p.1051-1061, 1996.

VERHAEGEN, D. et al. Quantitative trait dissection analysis in Eucalyptus using RAPD markers: I. Detection of QTL in Interespecific hybrid progeny, stability of QTL, expression across different ages. . Theoretical and Applied Genetics, v.95, p.597-608, 1997.

WELSH, J.; McCLELLAND, M. Fingerprinting genomes using PCR with arbitrary primers. Nucleic Acids Research, v.18, p.7213-7218, 1990.

R. Árvore, Viçosa-MG, v.31, n.1, p.13-24, 2007 
WILLIAMS, J.G.K. et al. DNA polymorphisms amplified by arbitrary primers are useful as genetic markers. Nucleic Acids Research, v.18, n.22, p.6531-6535, 1990.

ZENG, Z. B. Theoretical basis for separation of multiple linked gene effect in mapping quantitative trait loci. Proceedings of the National Academy of Sciences USA, v.90 p.10972-10976, 1993.
ZOBEL, B.; JETT, J. B. Genetics of wood production. Berlin: Springer-Verlag, 1995. 337p.

YOUNG, A.; BOYLE, T. J. B.; BOSCHER, D. Forest conservation genetics: Principles and practice. Australia: CSIRO, 2000.352p.

YOUSEF, G. G.; JUVIK, J. A., Comparison of phenotypic and marker assisted selection for quantitative traits in sweet corn. Crop Science, v.41, p.645-655, 2001. 